\title{
KRYTYKA IDEI „BEZWYZNANIOWOŚCI” W UJĘCIU WOJCIECHA DZIEDUSZYCKIEGO
}

\begin{abstract}
Streszczenie. W niniejszym artykule ukazana została polemika polskiego filozofa Wojciecha Dzieduszyckiego (1848-1909) z jednym z postępowych haseł głoszonych w XIX wieku. Hasło to sam Dzieduszycki określił jako „bezwyznaniowość”. Autor artykułu analizuje argumentację Dzieduszyckiego co do negatywnych skutków wyrugowania religii z życia publicznego, zarówno w przeszłości, jak i w czasach mu współczesnych, a także ukazuje pozytywną rolę religii w życiu jednostek, państw, narodów, a nawet całych cywilizacji. Bez religii bowiem, twierdził polski myśliciel, społeczności degradują się i obumierają. Ciekawa, a współcześnie bardzo ważna dyskusja o roli religii w życiu społecznym, została w artykule zestawiona z propagowaną przez Dzieduszyckiego ideą "mesjanizmu polskiego” (jako właściwej odpowiedzi na kryzys cywilizacyjny), jak również z obecnymi dziś w kulturze i polityce propozycjami radykalnej laicyzacji.
\end{abstract}

Słowa kluczowe: religia, bezwyznaniowość, państwo, społeczeństwo, naród, mesjanizm polski, idea postępu, cywilizacja

1. Wstęp. 2. Wojciecha Dzieduszyckiego rozumienie „bezwyznaniowości”. 3. Skąd się wzięła „bezwyznaniowość”? 4. Negatywne skutki „bezwyznaniowości”. 5. Argumenty Dzieduszyckiego broniące religii. 5.1. Religia służy dobru społeczeństw. 5.2. Religia jako źródło sensu. 5.3 Religia źródło trwałości i tożsamości narodowo-państwowej. 5.4. Religia - źródło wartości moralnych. 6. Mesjanizm polski jako odpowiedź na kryzys cywilizacyjny. 7. Ryzyko bezwyznaniowego świata.

\section{WSTĘP}

Hrabia Wojciech Dzieduszycki - polski społecznik, myśliciel i filozof - jest obecnie postacią mało znaną, a przecież w opinii wielu historyków był jednym z najpłodniejszych polskich umysłów końca 
XIX i początku XX wieku¹. Jego wszechstronne zainteresowania oraz patriotyczne i społeczne zaangażowanie budziło swego czasu powszechne uznanie. Dziś dostrzegamy, że wiele jego przemyśleń i społecznych obserwacji jest nadal aktualnych. Warto zatem przybliżyć postać i zapatrywania filozoficzne tego polskiego myśliciela. „Ateńczyk z Podola”, jak go określano, wiele uwagi poświęcił idei postępu społecznego, która w jego czasach była bardzo mocno upowszechniana. W swej twórczości zwrócił przede wszystkim uwagę na XIX-wieczne hasła, które wtedy stawały się synonimem postępu: bezwyznaniowość, nowa wizja rodziny, socjalizm, nacjonalizm. Twierdził, że idee te prowadzą ostatecznie do barbaryzacji, a w konsekwencji do upadku cywilizacji. W niniejszym tekście prześledzę i przybliżę czytelnikowi jedną z ówczesnych postępowych idei, którą Dzieduszycki określił jako „bezwyznaniowość”.

1 Dzieduszycki Wojciech - filozof, polityk, historyk sztuki, publicysta, powieściopisarz i dramaturg, tłumacz, poseł na sejm galicyjski ze stronnictwa konserwatystów, prezes Koła Polskiego w parlamencie wiedeńskim, poseł do Rady Państwa w Wiedniu, syn hrabiego Władysława. Urodził się 13 lipca 1848 roku w Jezupolu na Podolu galicyjskim, zmarł 23 marca 1909 roku w Wiedniu. Twórczość filozoficzna Dzieduszyckiego, zwłaszcza refleksja historiozoficzna, spotkała się z oddźwiękiem i uznaniem wśród współczesnych mu myślicieli katolickich, m.in. M. Zdziechowskiego, I. Chrzanowskiego, M. Straszewskiego. Twórca szkoły lwowsko-warszawskiej Kazimierz Twardowski uważał, iż Dzieduszycki „był tak wszechstronny, jak nim w ogóle być potrafi umysł ludzki". Twórczość literacka Dzieduszyckiego, głównie powieści i dramaty historyczne pisane w konwencji szekspirowskiej, nie przetrwały próby czasu, natomiast zalety osobiste, ogromna erudycja i entuzjazm społeczny, wywarły duży wpływ na współczesnych i potomnych. Jego barwna postać trafiła na karty wielu pamiętników i utworów literackich, m.in. do Słówek Boya. Uważano go za jednego z najoryginalniejszych ludzi swojej epoki, człowieka renesansu, górującego nad własnym pokoleniem wiedzą i wszechstronnością. Zob. T. Zawojska, Dzieduszycki Wojciech, w: Powszechna Encyklopedia Filozofii, t. II, red. A. Maryniarczyk, Lublin 2001, 788 . 


\section{WOJCIECHA DZIEDUSZYCKIEGO ROZUMIENIE „BEZWYZNANIOWOŚCI”}

Problem „bezwyznaniowości” polski myśliciel podejmuje bardzo konkretnie w jednym ze swoich dzieł: Dokqd nam iś́ wypada? (1910) Krytykując „hasła doby dzisiejszej”, na pierwszym miejscu wymienia właśnie „bezwyznaniowość”. Stwierdza, że jest czymś zupełnie nowym tak wielka niechęć, a wręcz „nienawiść dla wszelkiej religii, głoszona jawnie, przez cały zastęp ludzi, mieniących swoje uczucia jedynie postępowymi" 2 . Coraz więcej osób otwarcie i bez skrępowania mówi: „że pierwszym obowiązkiem postępowych ludzi i postępowych rządów jest walka ze wszystkimi wyznaniami, prowadzona wstępnym bojem, za pomocą książek popularnych, dzienników i wykładów publicznych, za pomocą bezwyznaniowej szkoły, narzuconej rodzicom i dzieciom przez przemoc państwa i za pomocą ustaw ograniczających wpływ duchowieństwa”.

Oczywiście są także ludzie bardziej umiarkowani, którzy wprawdzie nie żywią otwartej nienawiści, ale okazują wobec wszelkiej religii obojętność, a nawet pogardę. Obydwie grupy wyznają zasadę, że „nikomu żadnej religii, ani braku religii nie wolno narzucać i że władza nie powinna troszczyć się o religię". Co więcej, państwu nie wolno nadawać religijnego charakteru ${ }^{4}$. Ateiści z czasów Dzieduszyckiego przekonywali, że religia ma być sprawą prywatną i nie może być w jakikolwiek sposób manifestowana w życiu publicznym. Referując ich stanowisko, Dzieduszycki pisał, że religia nie może być obecna: „ani w szkołach, ani w prawodawstwie małżeńskim, ani w sądach, szpitalach, wojsku, czy jakiejkolwiek rzeczy utrzymywanej z funduszów publicznych. Religia ma być po prostu cierpianą,

2 W. Dzieduszycki, Dokąd nam iść wypada?, w: Tenże, Dokąd nam iść wypada?; Mesjanizm polski a prawda dziejów, Kraków 2012, 106.

3 Tamże, 106.

4 Por. Tamże, 106. 
jako rzecz prywatna”, bo przecież to „przeżytek z czasów ciemnoty i barbarzyństwa" 5 .

Zwolennicy postępowej idei bezwyznaniowości uważali, że religia jest przeszkodą na drodze do ostatecznego progresu, stąd trzeba ją zwalczać wszelkimi sposobami. Należy wykazywać naukowo, że religia jest zabobonem, mitem, bajką; ośmieszać i dezawuować ją na polu historycznym i kulturowym. Każdego zaś, kto będzie próbował religii bronić, trzeba nazwać obskurantem, zacofańcem, klerykałem i reakcjonistą. Propagatorzy tych tez przekonywali, że jest tylko kwestią czasu, kiedy prawdziwa nauka wyprze religię i zajmie jej miejsce. Symptomem postępowej i rozwiniętej cywilizacji ma być bowiem brak wszelkiej religii, nauka zaś wyjaśni wszystko - to, co uważaliśmy do tej pory za niezrozumiałe, a czemu przypisywaliśmy walor nadprzyrodzony. Powstanie świata, sens istnienia człowieka, choroby, kataklizmy - już niedługo tajemnica świata oraz człowieka zostanie odkryta i ujęta dzięki ludzkiej rozumności. W tej perspektywie dogmaty wiary przestaną obowiązywać, a moralność oparta na religii straci swą rację bytu i zostanie zastąpiona przez racjonalnie opracowane normy i zasady ${ }^{6}$. W duchu tak rozumianej bezwyznaniowości z obecną w społeczeństwie religią (zwłaszcza katolicką), miało również walczyć państwo, bowiem państwa bardziej cywilizacyjnie rozwinięte powinny interweniować w tych krajach, w których mocny jest jeszcze zabobon wiary. Również naciski ekonomiczne powinny być tak mocne, aby wymuszać porzucenie religii

5 Tamże, 106. Zob. W. Dzieduszycki, Listy o wychowaniu, Lwów 1892, 23 nn.

6 Por. W. Dzieduszycki, Dokąd nam iść wypada?, dz. cyt., 107.

7 Por. W. Dzieduszycki, Mesjanizm polski a prawda dziejów, w: Tenże, Dokąd nam iść wypada?; Mesjanizm polski a prawda dziejów, Kraków 2012, 617-618. 


\section{SKĄD SIĘ WZIĘŁA „BEZWYZNANIOWOŚĆ”?}

„Świat stracił duszę, zdrętwiał, zniedołężniał; żyje tylko chęcią zmysłowej rozkoszy i materialnego zysku; chyli się ku upadkowi”8 takimi słowami opisywał Dzieduszycki kondycję swoich czasów. Słychać w tych skargach echa wygłaszanych pół wieku wcześniej diagnoz Zygmunta Krasińskiego: „Krytyka rozumu zniszczyła wszelką wiarę dawną, wszelkie życie żywiące śród ludów, a nic równie żywotnego lub żywotniejszego na to miejsce nie postawiła. Gdzie tylko spojrzeć w świecie ducha ruiny, swawola, roztrój - quot capita, tot sensus" (Ile gtów tyle opinii, Horacy).

Dla Dzieduszyckiego „upadek religii i utrata duszy” mają swą genezę w protestanckiej Reformacji. I choć polski myśliciel przyznaje wprawdzie protestantyzmowi pewne zasługi (np. na polu czytania i wyjaśniania Pisma Świętego), to jednak uważa, twórcy Reformacji popadli w skrajność, a ich działania przyczyniły się do subiektywizmu, anarchii moralnej, a ostatecznie do znacznego osłabienia chrześcijaństwa ${ }^{10}$. „Ale zwalczając wiarę, ślepo przyjętą, narzuconą, przymusową, a zatem najczęściej nierzetelną, nie dostrzegli protestanci, że przykładają siekierę do pnia religii, którą gorąco wyznawali. Wraz z feudalną, ziemską księży przewagą odrzucili tradycję i stróża jej nieomylnego, pozwolili zrazu ludziom dowolnie Biblię tłumaczyć, wnet potem zezwolili na to, aby każdy to w księgach świętych pod pozorem fałszerstwa odrzucał, co mu się nie podobało i musieli wreszcie doprowadzić do tego, iż każdy już nie Biblię, ale własne mniemanie najwyższym sędzią w sprawach religii ustanowił, musieli chrześcijaństwo uczynić pozorem tylko, a rzeczywistością racjonalizm, anarchię moralną, która dziś Europę zalega, która wszelki wspólny

8 Tamże, 605.

9 Z. Krasiński, Przedświt, Warszawa 1928, 3-4.

10 Por. T. Zawojska, Od epistemologii do historiozofii. Poglądy filozoficzne Wojciecha Dzieduszyckiego, Lublin 2011, 251. 
potępiła dogmat, drzwi na oścież otworzyła dla braku obyczajności rozkładającego życie rodzinne i społeczne, wierzy jedynie w rację stanu, zezwala na każdą publiczną zbrodnię, przyklasnąć gotowa rozbojowi i kradzieży, byle się powiodły i byle były ogromne"11.

Szukając przyczyn zła, które zniekształciło stosunki polityczne, społeczne oraz rodzinne, Dzieduszycki dochodzi do wniosku, że ma ono swe źródło w pogardzie dla tradycji i religii z jednoczesnym daniem pierwszeństwa zabsolutyzowanemu rozumowi. Proces ten zapoczątkowała Reformacja oraz stworzona przez renesans idea humanizmu, odrywająca stopniowo człowieka od Boga. Pogłębiła go i ugruntowała Wielka Rewolucja Francuska, motywowana dodatkowo XVIII-wieczną filozofią oświeceniową ${ }^{12}$. W Mesjanizmie polskim pisał: „Przecież dopiero francuscy Encyklopedyści stanowczo u nowożytnych podkopali wiarę w religię i w feudalny, na Bożej łasce oparty porządek świata; przecie Rewolucja francuska i wojny napoleońskie są zdarzeniem, niemniej doniosłem od Renesansu i Reformacji; one to zwaliły tradycyjny ustrój w całej Europie"13.

Promotorami tak ujętych prądów antyreligijnych w czasach polskiego myśliciela byli materialiści L. Büchner, a także socjaliści oraz pozytywiści, tacy jak A. Comte, H. Spencer czy H.A. Taine. W swej twórczości starał się więc Dzieduszycki zwalczać ich poglądy, postulując powrót do tradycji i religii1 ${ }^{14}$. Negatywną opinię haseł pozytywizmu

11 W. Dzieduszycki, Mesjanizm polski a prawda dziejów, dz. cyt., 607.

12 Por. K.K. Daszyk, Osobliwy Podolak. W kręgu myśli historiozoficznej i społeczno-politycznej Wojciecha hr. Dzieduszyckiego, Kraków 1993, 46. Por. T. Zawojska, Ku chrześcijańskiej wspólnocie Europy. Refleksje myślicieli polskich z początku XX stulecia. W. Dzieduszycki i M. Zdziechowski, w: Światopoglądowe odniesienia filozofii polskiej, Lublin 2011, 284.

13 W. Dzieduszycki, Mesjanizm polski a prawda dziejów, dz. cyt., 608.

14 Por. K.K. Daszyk, Osobliwy Podolak, dz. cyt., 48. Dzieduszycki w Listach czytelnika, kolejno dokonuje krytyki: Büchnera (s. 65 nn.); Taine’a (s. 125 nn.); socjalizmu, a zwłaszcza Marksa (s. 217 nn.); pozytywizmu, w tym Comtea i Spencera (s. 328 nn.). Zob. W. Dzieduszycki, Listy czytelnika, Lwów 1893. Ludwig Büchner (1824-1899) - był niemieckim filozofem, fizjologiem i lekarzem, który stał się jednym z propagatorów XIX-wiecznego materializmu naukowego. Hipolit Taine (1828-1893) - francuski filozof, psycholog, historyk sztuki 
przedstawił w wydanym w krakowskiej drukarni dziennika „Czas” utworze Uczone fantazje ${ }^{15}$. W krótkim felietonie bronił przede wszystkim prawd moralnych wynikających z chrześcijaństwa, idei Boga-Stwórcy i duszy nieśmiertelnej. Przeciwstawiał się pozytywistycznemu ateizmowi scjentystów, afirmując teizm i postawy płynące $z$ wiary ${ }^{16}$.

\section{NEGATYWNE SKUTKI „BEZWYZNANIOWOŚCI”}

Nie należy jednak sądzić, że Dzieduszycki negował czasy, w których żył. Przeciwnie, postrzegał ówczesne przemiany pozytywnie. Uważał, że dzięki postępowi społeczno-politycznemu zwyciężyła w Europie idea parlamentaryzmu i narodowości, zaś zmiany techniczne i naukowe przynoszą podniesienie jakości życia społeczeństw starego kontynentu. Zauważał jednakże, iż pośród tych osiągnięć i sukcesów mnożą się również negatywne postawy dekadenckie. Okazuje się bowiem, że „dobrobyt” nie daje wybawienia ludzkości, wręcz przeciwnie - na początku XX wieku przyszłość jawiła się wielu ludziom bardzo pesymistycznie ${ }^{17}$. Narody Zachodu, jak mówił Dzieduszycki: „posiadają [już] gorąco pożądane, krwawo wywalczone dobra, wymarzony raj konstytucyjny i z rozczarowaniem patrzą na to, że przecie prawdziwego raju nie ma na świecie, że nędze i troski są, jak były, że występek i bezprawie tylko nową przybrały postać"18.

Było to dla niego dowodem, że idea postępu ze swą negacją religii i hasłem „bezwyznaniowości” poniosła klęskę. Uważał, że stało się tak właśnie dlatego, że walczono z wiarą, z chrześcijaństwem,

i literatury oraz krytyk literacki. Karol Marks (1818-1883) - niemiecki filozof, socjolog, ekonomista, historyk, dziennikarz i działacz rewolucyjny, twórca socjalizmu naukowego. Auguste Comte (1798-1857) - francuski filozof i pozytywista, twórca terminu socjologia. Herbert Spencer (1820-1903) - angielski filozof i socjolog.

15 Zob. W. Dzieduszycki, Uczone fantazje, Kraków 1871.

16 Por. T. Zawojska, Od epistemologii do historiozofii, dz. cyt., 57 n.

17 Por. K.K. Daszyk, Osobliwy Podolak, dz. cyt., 47. Por. T. Jakubiec, Wojciech Dzieduszycki. Pisarz, estetyk, filozof, Kraków 2009, 33.

18 W. Dzieduszycki, Wiek XIX, Kraków 1900, 8. 
a szczególnie z katolicyzmem. Jak sam wyznał: „doświadczenie nas uczy, iż trzymanie się tej [katolickiej] religii jest rękojmią szczęśliwego rozwoju społeczeństw”19. Prześledzenie historycznego rozwoju kultur pokazuje bowiem, że rozwijają się tylko te wspólnoty, które uznają zasady wypływające $z$ wiary religijnej i na tych zasadach opierają ład społeczny. Jednak nie każda wiara religijna przyczynia się do rozwoju cywilizacji. Czyni to tylko taka, która, jak katolicyzm, trzymając się swych podstawowych zasad, pozostawia rozumowi i przedsiębiorczości ludzkiej swobodę w sferze pozareligijnej²0. Istotą prawdziwego postępu i cywilizacji jest zatem postawa kierowania się w postępowaniu moralnymi prawami ustanowionymi przez Opatrzność. Istota cywilizacji nie zasadza się zatem na komforcie życia. „Nie ten naród jest cywilizowany, który ma najlepsze gościńce i najpiękniejsze karczmy, tylko ten, który ma więcej obywatelskiego ducha, poświęcenia i miłości"21.

\section{ARGUMENTY DZIEDUSZYCKIEGO BRONIĄCE RELIGII}

\subsection{RELIGIA SŁUŻY DOBRU SPOŁECZEŃSTW}

Reakcją na areligijne, a często nawet antyreligijne prądy myślowe XIX wieku był zwrot ku wierze i religijności, który dokonał się pod koniec tego stulecia. Zaczęto postulować religię jako jedną z najistotniejszych kwestii w życiu człowieka. Sprzyjało to także odrodzeniu się idei romantycznych, narodowych i mesjanistycznych. Do kręgu takich myślicieli można zaliczyć również Wojciecha

19 W. Dzieduszycki, Listy czytelnika, dz. cyt., 367.

20 Por. T. Zawojska, Dzieduszycki Wojciech, t. II, dz. cyt., 791. Por. T. Zawojska, Od epistemologii do historiozofii, dz. cyt., 254.

21 W. Dzieduszycki, Listy ze wsi, Lwów 1889, 279. Por. T. Zawojska, Od epistemologii do historiozofii, dz. cyt., 267. 
Dzieduszyckiego ${ }^{22}$. Ateńczyk z Podola, uzasadniając swoje tezy i polemizując $z$ entuzjastami idei „bezwyznaniowości”, wskazuje najpierw na doniosłą rolę, jaką religia odegrała w historii. Używa argumentu historycznego, aby poprzez przeszłe doświadczenia ukazać, jaką wartością jest dla społeczeństwa religia. Przede wszystkim pamiętajmy, zaznacza Dzieduszycki, że w Europie chrześcijaństwo przeprowadziło całe pokolenia przez trudne czasy barbarzyństwa, kończące epokę starożytną. Społeczności naszego kontynentu pogrążone były wtedy w zamęcie moralnym i społecznym, mnożyły się „występek i rozpusta”. Ratunkiem dla ówczesnej Europy stało się chrześcijaństwo z Ewangelią miłości, z moralnością opartą na Dekalogu, z wartościami uniwersalnymi, z porządkiem polityczno-społecznym ${ }^{23}$. Chrześcijaństwo ,ugruntowało teokrację nową, wychowawczynię zdziczałego Zachodu, teokrację, nie przyrodniczą już, nie partykularną i politeistyczną, ale duchową, chrześcijańską, uniwersalną, mająca przewodzić ludzkości na drodze nieskończonego postępu. Papiestwo ujęło świat w swoje ręce, ten świat wychowało, nauczyło znowu ludzi ładu i zgody, dało im ideał, przez tysiąc lat uprawiało rolę pod nowy zasiew drugiej postępowej cywilizacji, wśród której dziś żyjemy, która się wydaje zagrożona upadkiem i zgubą"24.

Dla kontrastu - mówi Dzieduszycki - zobaczymy, że państwa i narody, które nie służyły żadnej religii, a były oparte jedynie na strachu i przemocy albo jakimś innym przymusie zewnętrznym, nie przetrwały próby czasu i „,rozpłynęły się w odmętach historii”. Oprócz pamięci nic po nich dziś nie pozostało. Przykładem są Hunowie, którzy za czasów Attyli wstrząsnęli Europą, ponieważ jednak nie służyli żadnej religii, nie zdołali założyć trwałego państwa. Podobnie Mongołowie, którzy pod wodzą Czyngis-chana byli przecież

22 Por. T. Zawojska, Religijno-patriotyczne podstawy narodowych aspiracji Polaków u progu XX stulecia w świetle poglądów Wojciecha Dzieduszyckiego, w: Cywilizacja. O nauce, moralności, sztuce i religii 48(2014), 33-34.

23 Por. W. Dzieduszycki, Mesjanizm polski a prawda dziejów, dz. cyt., 600 nn.

24 Tamże, 602. 
postrachem całego świata. I choć Czyngis-chan przekazał berło swojemu potomstwu, to jednak jego imperium nie przetrwało ${ }^{25}$. Podobnie stanie się - twierdził polski myśliciel - z narodami Europy, jeśli nie powrócą do religii. Dlatego z ironią stwierdza: „stronnictwa rewolucyjne i radykalne mają religię, a różnych sekt wspólny dogmat, wiarę w postęp konieczny narzucić społeczeństwom wszystkim, tak że nikt, prócz niektórych odosobnionych katolików wierze w postęp głośno kłamu zadać nie chce"26. Jeśli odrzuca się wiarę w Boga i wszelkie związane z tym dogmaty, wartości oraz normy moralne, to musi się to skończyć upadkiem naszej cywilizacji, a przynajmniej doprowadzić do rozbicia społeczeństwa i jego barbaryzacji ${ }^{27}$.

\subsection{RELIGIA JAKO ŹRÓDŁO SENSU}

Znaczna część życia Dzieduszyckiego przypadała na okres względnego spokoju w Europie, nazywany La belle époque. „Piękną epokę” datuje się na lata 1871-1914. Cechowała ją wiara w ogólnoludzki postęp i dobrobyt. Jednak pod koniec XIX wieku wiara ta zachwiała się i pojawiły się postawy dekadenckie ${ }^{28}$. Pojawianie się tychże dekadenckich nastrojów zauważał również hrabia Wojciech. Myśliciele tacy jak Hartmann, Tołstoj czy Ruskin głosili rychły koniec ludzkości ${ }^{29}$. Także polski myśliciel sądził, że jeśli świat nadal będzie „W sobie zabijał duszę," to doprowadzi do swej własnej zguby. Jedynym ratunkiem jest powrót do religii, do tradycji, do wartości. „Człowieka różni naprawdę od zwierząt jedynie uczucie religijne; bez niego byłby tylko

25 Por. W. Dzieduszycki, Dokąd nam iść wypada?, dz. cyt., 110.

26 Tamże, 110.

27 Por. Tamże, 113-114, 118.

28 Por. T. Zawojska, Ku chrześcijańskiej wspólnocie Europy, dz. cyt., 285, 287 n.

29 Por. W. Dzieduszycki, Mesjanizm polski a prawda dziejów, dz. cyt., 624. Także w jednym ze swych listów Dzieduszycki dokonuje krytyki poglądów Eduarda von Hartamanna i Lwa Tołstoja oraz popularnych wówczas nurtów, takich jak spirytualizm czy też stosowanie hipnozy. Zob. W. Dzieduszycki, Listy czytelnika, dz. cyt., 376 nn. 
bardzo przemyślną, bardzo złośliwą i obrzydliwą małpą. Ludzkość nowożytna pracuje nad tym przemocą, aby w sobie wszelką religię przytłumić i dojdzie do wszelkiej religii ustnego zaprzeczenia! Małpą szczęśliwą i zdrową jednak człowiek być nie potrafi; dusza, tęskniąca przemocą do jakiegoś Boga, do jakiegoś ideału, udręczy ludzi nowożytnych, tak, że w męce swojej muszą dążyć świadomie lub nieświadomie do gromadnego samobójstwa. Po szaleństwie i po orgii dzisiejszej nie będzie zatem ruiny, nastanie nicestwo"30.

Dzieduszycki bardzo wyraźnie dostrzegał kryzys ogarniający świat zachodni w zakresie kultury, gospodarki, polityki i relacji międzyludzkich, w odwróceniu wartości i pomieszaniu pojęć. Ten zamęt realnie wpływał na nastroje jednostek i społeczeństw, również na samego Dzieduszyckiego, który uważał, że jeśli się tej anarchii nie powstrzyma, niechybnie doprowadzi cywilizację łacińską do upadku. Remedium na taki stan rzeczy jest religia katolicka, której zasady i wartości należy wprowadzić $\mathrm{w}$ życie publiczne ${ }^{31}$. W takiej perspektywie religia jawi się jako źródło sensu dla udręczonej ludzkiej egzystencji. Jest tym, co fundamentalnie odróżnia człowieka od zwierząt, wyraża jego naturalne pragnienia i tęsknoty, nadaje rzeczywisty sens życiu. Nie można zatem walczyć z religią, ale należy wykorzystać ją jako antidotum na bolączki współczesnego świata, na pesymizm, bezsens i mnożące się dekadenckie postawy. Tylko religia potrafi dać człowiekowi odpowiedzi na najważniejsze pytania egzystencjalne, zapewnia poczucie sensu, bezpieczeństwa i pokoju. Bez niej człowiek staje się jedynie „bardzo przemyślną, bardzo złośliwą i obrzydliwą małpą" i jako taki nie jest zdolny stworzyć trwałej cywilizacji. Ostatecznie to, co zbuduje, zostanie doprowadzone do ruiny i nihilizmu. Widząc postępujące odejście od religii, Dzieduszycki postawił też pytanie: czy upadek ludzkości jest przesądzony, niejako nieuchronny? Odpowiadał, że nie, jeśli powróci się do wiary,

30 W. Dzieduszycki, Mesjanizm polski a prawda dziejów, dz. cyt., 624.

31 Por. T. Zawojska, Ku chrześcijańskiej wspólnocie Europy, dz. cyt., 272 n. 
do religii, do ducha: „Czy to poczucie religijne, ta potrzeba ideału i Boga, tkwiąca w głębi ludzkiej duszy, nie jest raczej poręką lepszej promiennej przyszłości? (...) Na to, aby ludzkość wyratować przed nieszczęściem i samobójstwem, potrzeba tylko wyraźnej, stanowczej, religijnej afirmacji, niepotępiającej tego, co nowożytna ludzkość zdobyła, a wskazującej tylko słuszny użytek z nauki, umiejętności, demokracji, powszechnej oświaty"32.

\subsection{RELIGIA - ŹRÓDŁO TRWAŁOŚCI I TOŻSAMOŚCI NARODOWO-PAŃSTWOWEJ}

Zauważmy jednak, że dla Dzieduszyckiego religia nie była jedynie ratunkiem przed nihilizmem. Rozumiał ją jako skuteczne źródło tożsamości narodowej i nieocenioną pomoc dla państwa. Uważał wręcz za konieczną, by tworzyć trwałe społeczeństwo, jest bowiem elementem spajającym i dającym tożsamość członkom danej społeczności ${ }^{33}$. Ta funkcja jednocząca jest szczególnie ważna, bo słowo religia oznacza, według Dzieduszyckiego, „węzeł łączący całe społeczeństwo, a tym węzłem bywa system przekonań wspólnych, o których nikt nie wątpi, nikt wątpić nie śmie, co do których nikt nawet przeciwnych argumentów słuchać nie chce, a które się tyczą spraw tak ważnych, że poręczają wspólne postępowanie wszystkich członków społeczeństwa, w tych wypadkach, w których żadnemu zewnętrznemu nie ulegają przymusowi i nawet wtedy, kiedy to postępowanie sprowadzić może na wiernych tej religii wyznawców klęski i prześladowania" ${ }^{34}$.

Przy czym religia ta może być zarówno religią ojczyzny (jak u starożytnych, Japończyków i wielu Europejczyków), religią dogmatyczną, opartą na objawieniu, a także religią postępu, rewolucji,

32 W. Dzieduszycki, Mesjanizm polski a prawda dziejów, dz. cyt., 624 n.

33 Por. T. Jakubiec, Wojciech Dzieduszycki, dz. cyt., 32.

34 W. Dzieduszycki, Dokąd nam iść wypada?, dz. cyt., 106. 
socjalizmu, anarchizmu bądź staroświecką religią honoru ${ }^{35}$. Oczywiście niektóre $\mathrm{z}$ tych przedmiotów religijnej czci mogą się wymieszać i zrosnąć w jedno, jednak zawsze to, w co ludzie wierzą, musi uchodzić za najwyższe dobro. $Z$ natury rzeczy religia nie może więc być sprawą indywidualną czy prywatną. Niestety, jak stwierdza Dzieduszycki, w XIX wieku zbyt mocno rozpowszechnił się zamęt duchowy i skrajny subiektywizm, które w konsekwencji doprowadzają do anarchii. Społeczeństwo niezdolne do wspólnego działania musi się rozpaść. Można jednak wskazać dwa warunki, twierdził Dzieduszycki, które sprawią, że nie dokona się społeczny rozkład. Są nimi: przymus zewnętrzny państwa albo religia polegająca na prawdziwym wolnym wyborze. Dzieduszycki opowiada się za tym drugim rozwiązaniem, gdyż uważa, że tylko ono pozwoli stworzyć trwałe więzi społeczne ${ }^{36}$. Intuicję tę potwierdza w Mesjanizmie polskim: „Są prawa psychologiczne czy moralne, czy jak je kto nazwie, ale łatwo zrozumiałe, które tłumaczą wzrost i upadek, a także następstwo narodów tak w starożytności, jak za czasów nowszych i które o dzisiejszej cywilizacji źle wróżyć każą. Narody wtedy bywają zdrowe i zgodne, wtedy trwają, wtedy tylko wspólnym życiem żyją, jak są wspólne dogmaty, nie tylko religijne, ale także społeczne, o których nikt nie wątpi. Gdzie o wszystkim wątpić wolno, gdzie się o wszystko toczy spór w narodzie, tam nie długie jego w dziejach mieszkanie, tam egoizm jednostek wszystko rozsadzić, stoczyć musi, wreszcie musi doprowadzić do ostatecznego upadku" ${ }^{37}$.

Dla Polaków, twierdzi Dzieduszycki, szczególnie ważna jest religia katolicka, bo to ona jest najważniejszym czynnikiem organizującym tożsamość narodową. Za bardzo niebezpieczne uważa zatem nakłanianie narodu, aby odstąpił od swej wiary. Wprost mówi, że jest to wręcz popychaniem go ku samobójstwu: „Kto nakłania naród do

35 Zob. tamże, 109.

36 Por. tamże, 108-109.

37 W. Dzieduszycki, Mesjanizm polski a prawda dziejów, dz. cyt., 590. 
odstąpienia od katolicyzmu, ten pcha go ku samobójstwu, pomaga tym, którzy chcą zatraty polskiego imienia”38. Wiara i Kościół są bowiem „najsilniejszą zaporą wstrzymującą lud nasz od zatracenia swej narodowości”39. To kluczowe czynniki wspólnototwórcze ${ }^{40}$.

\subsection{RELIGIA - ŹRÓDŁO WARTOŚCI MORALNYCH}

Dzieduszycki przedstawiał krytyczną diagnozę ówczesnego stanu cywilizacyjno-kulturowego Europy. Jako lekarstwo na wyjście z kryzysu wskazywał chrześcijańskie zasady etyczne ${ }^{41}$. Dlatego uważał, że najważniejszą funkcją religii jest to, iż praktykowana staje się nośnikiem wartości moralnych. W dobie industrializmu przemysł, technika i wielkomiejski styl życia odrywają człowieka od rodziny, tradycji i moralności. „Ludzie toną w Babilonie wielkich miast, zmieniają się w koła bezdusznej maszyny nowożytnego społeczeństwa, wiodą życie niespokojne, nerwicowe, chciwe, namiętne, wśród mechanicznych wynalazków, które ich ze wszystkim odrywają od natury"42.

Dla Dzieduszyckiego wszystko to dzieje się między innymi dlatego, że zaczęto negować religię, która jest przecież formą promowania postaw moralnych. Porzucenie religii doprowadza do tego, że ludzie popadają w marazm, nie mają czasu myśleć, tworzyć, interesować się nauką, sztuką czy literaturą, stawiać ważnych pytań i poszukiwać na nie wiążących odpowiedzi. Przestają od siebie wymagać, szukając tego tylko, co przyjemne i użyteczne. Brak religii spłaszcza moralność i prowadzi do barbaryzacji społeczeństwa ${ }^{43}$. Jak stwierdza Dzieduszycki: „Dziś burzymy wszyscy, mieszkamy po namiotach

38 Tamże, 539.

39 Tamże, 539.

40 Por. A. Kosiecka-Pajewska, Zachowawcza myśl polityczna w Galicji w latach 1864-1914, Poznań 2002, 209-210; Por. W. Dzieduszycki, Dokąd nam iść wypada?, dz. cyt., 16-17.

41 Por. T. Zawojska, Ku chrześcijańskiej wspólnocie Europy, dz. cyt., 270.

42 W. Dzieduszycki, Mesjanizm polski a prawda dziejów, dz. cyt., 582.

43 Por. tamże, 582. Por. A. Kosiecka-Pajewska, Zachowawcza myśl polityczna, dz. cyt., 215. 
i szałasach, które się lada chwila zawalą, albo spłoną i koczować możemy długo i zmarnieć wśród nowych średnich wieków gorszego barbarzyństwa, jeśli się nie znajdą ludzie, którzy na nowo dźwigną gmach chrześcijaństwa, na tej samej odwiecznej podstawie. Nowej religii ludzkości nie trzeba, ale potrzeba jej chrześcijaństwa zupełnego; trzeba, aby zasady chrześcijańskiej moralności zastosowano także do życia publicznego"44.

Pośród różnych religii to właśnie religia chrześcijańska jest źródłem najzdrowszej moralności i tylko ona może podźwignąć ludzkość z upadku, tak jak to zdarzało się już w historii: „kto krzyż wyniesie ponad samolubstwo narodów i stanów, ten stanie się ludzkości wodzem, nowego wieku budowniczym"45. Musi zatem znaleźć się - mówi polski uczony - jakiś naród, który moralność chrześcijańską wcieli w życie i przystąpi do „budowy nowego świata naprawdę chrześcijańskiego"46. Jeśli tak się stanie, to być może unikniemy „strasznej katastrofy dziejowej; cywilizacja nie runie, a przemieni się tylko" ${ }^{47}$. Jak wyznaje z nadzieją: ,świat rozpromienieje katolicyzmem, opartym na swobodnym przekonaniu nawróconych łaską Bożą, a nie pańskim rozkazem i ładem społecznym, opartym na miłości braterskiej obywateli między sobą, na stosunku ojcowskim, a nie pańskim władzy do poddanych" 48 .

Wedle polskiego historiozofa głęboka afirmacja religijna mogła dokonać się jedynie $\mathrm{z}$ inicjatywy papieża, który w tamtych czasach był jeszcze dla świata jednym $z$ najważniejszych autorytetów. Aby w pełni dojrzało dzieło moralnego odrodzenia, trzeba, by przynajmniej jakiś jeden naród wprowadził tę naukę w czyn, najpierw poprzez wytrwałą pracę i cnotliwe życie poszczególnych jednostek, a potem wobec coraz większej rzeszy społeczeństwa. Jednak - jak

44 W. Dzieduszycki, Mesjanizm polski a prawda dziejów, dz. cyt., 610.

45 Tamże, 610.

46 Tamże, 611.

47 Por. tamże, 610.

48 Tamże, 611. 
zaznacza Dzieduszycki - odrodzenie owo nie dokona się w żadnym z narodów Zachodu, one są już zbyt zepsute. Pozostają jedynie narody słowiańskie, a wśród nich dwa wielkie narody: rosyjski i polski. Naród rosyjski, którego główną cechą, według polskiego myśliciela, jest rezygnacja z wszelkich dążeń, nie jest w stanie podjąć się realizacji tego zbawczego zadania w dziejach. Pozostają zatem Polacy. Mimo swych wad, nasz naród kultywuje ideę moralnego dobra ucieleśnioną w idei ojczyzny. Dlatego to właśnie Polacy - twierdzi Dzieduszycki - są szczególnie predestynowani do tego, by pokonać rozlewającą się nieprawość. W tym celu należy w narodzie polskim kultywować podstawowe cnoty społeczne: sprawiedliwość, uczciwość, ofiarność, pracowitość, wytrwałość, honor oraz walczyć z największym narodowym grzechem - zawiścią - która tłumi inicjatywę jednostek wybitnych, zdolnych i twórczych ${ }^{49}$.

\section{MESJANIZM POLSKI JAKO ODPOWIEDŹ NA KRYZYS CYWILIZACYJNY}

Dopiero dzięki tak nakreślonej perspektywie widać, że - według polskiego myśliciela - przed ludzkością stoi kluczowe zadanie: wprowadzenie wartości i moralności chrześcijańskiej do życia publicznego. I choć cywilizacja nowożytna ,jest tak silną i tak mocno zorganizowaną, że przetrwa jeszcze wieki”, to jednak zaczyna chylić się ku upadkowi ${ }^{50}$. Ta pesymistyczna wizja może się ziścić, ale nie musi. Tak jak niegdyś Kościołowi udało się wprowadzić moralność w stosunki rodzinne i prywatne, przekształcając ludzi z nieokrzesanych barbarzyńców w budowniczych nowożytnej cywilizacji, tak teraz należy moralność wprowadzić do polityki, aby zapobiec degradacji kultury $^{51}$. Koniec zachodniej cywilizacji nie jest więc przesądzony, jednak „tylko chrześcijaństwo może tę zgubę odwrócić, ale musi to

49 Por. tamże, 625, 630.

50 Por. tamże, 636-637.

51 Por. tamże, 637. Por. T. Jakubiec, Wojciech Dzieduszycki, dz. cyt., 46. 
być chrześcijaństwo zupełne, domagające się miłości, sprawiedliwości, cnoty ewangelicznej, także w stosunkach narodu z narodem, stronnictwa ze stronnictwem" 52 .

Uważał, że dzięki chrześcijaństwu, a szczególnie katolicyzmowi, ludzkość może odrodzić się moralnie i zażegnać kryzys cywilizacyjny. Papieże, mający w świecie autorytet moralny, mogą wskazać prawidłowy kierunek rozwoju ludzkości53. Taką odnowę rozpoczął już niezwykle ważny dla XIX wieku papież - Leon XIII ${ }^{54}$. Jego dzieło należy kontynuować, wcielać w życie. Musi znaleźć się naród, który uzna w jego spełnieniu swoje powołanie, swoją misję dziejową i będzie przewodził przede wszystkim pod względem moralnym. I tutaj Dzieduszycki widzi szansę dla Polski, gdyż, jak wspomniałem wcześniej, sądził, że Zachód nie jest w stanie tego uczynić, a z narodów słowiańskich jedynie Polska może się podjąć tego zbawczego zadania ${ }^{55}$. Podobnie jak w romantyzmie, pojmował naród jako wspólnotę duchową, tworzącą kulturę skupioną wokół narodowego ideału moralnego. Nośnikiem zaś tej moralności jest

52 W. Dzieduszycki, Mesjanizm polski a prawda dziejów, dz. cyt., 638.

53 Por. T. Zawojska, Religijno-patriotyczne podstawy, dz. cyt., 36.

54 Papież Leon XIII był bardzo aktywny we wskazywaniu społecznych i politycznych niebezpieczeństw jakie grożą chrześcijaństwu, dlatego dużą uwagę poświęcał sprawom społecznym. Już na początku pontyfikatu pisał na temat państwa, pochodzenia władzy cywilnej oraz demokracji (encyklika Diuturnum illud, 1881 rok). Cztery lata później wydał Immortale Dei, gdzie wypowiedział się o ustroju państwa chrześcijańskiego oraz zawarł swego rodzaju kodeks chrześcijańskiej polityki. Określił także zakres władzy duchowej i świeckiej, podkreślił, że każda władza jest legalna, o ile zapewnia dobrobyt społeczny. W 1888 roku w encyklice Libertas praestantissimum, wykazywał, że Kościół winien być strażnikiem dobrze rozumianej wolności. Stał się znany jako autor pierwszej i najważniejszej encykliki społecznej Rerum novarum (1891 rok), w której przedstawił zasady katolickiej nauki społecznej, potępił socjalizm, apelował o uczciwą płacę, zapewnienie praw robotnikom i postulował tworzenie związków zawodowych. Por. J.N.D. Kelly, Encyklopedia papieży, tłum. z ang. T. Szafrański, Warszawa 1997, 435-438. Zob. J. Majka, Katolicka Nauka Społeczna. Studium Historyczno-doktrynalne, Rzym 1986, 155-160. Por. T. Zawojska, Religijno-patriotyczne podstawy, dz. cyt., 36.

55 Por. W. Dzieduszycki, Mesjanizm polski a prawda dziejów, dz. cyt., 638. Por. T. Zawojska, Od epistemologii do historiozofii, dz. cyt., $274 \mathrm{nn}$. 
kultura: literatura, filozofia, dzieła sztuki, wspólne zasady moralne ale nade wszystko religia ${ }^{56}$.

W ten sposób zrodziła się w „Ateńczyku z Podola” myśl o polskim mesjanizmie: „I oto z rozmów i rozmyślań wychyliła się we mnie ostatecznie myśl, w istocie swojej nie różna od nauk mesjanizmu polskiego. Nie masz w niej ani przyrównania Polski do Chrystusa, ani oczekiwania cudu, ani nadziei rychłego zmartwychwstania ojczyzny, sprowadzonego nagłym dzisiejszych państw upadkiem, ani kultu napoleońskiego, ani kacerskiej przymieszki i mistycyzmu, przeciwstawiającego katolicyzmowi nowe jakieś polskie objawienie. Ale jest przekonanie, że zadaniem Polski wprowadzić do dziejów moralność polityczną i społeczną - że to narodu naszego opatrznym powołaniem" 57 . Jak możemy się przekonać, Dzieduszycki zredefiniował romantyczne podejście do mesjanizmu. Choć Polska ma szczególne posłannictwo w dziejach narodów, to jednak nie dokonuje się ono drogą walki, cierpienia czy ofiary lub jakiegoś cudu, ale przez przyczynienie się do moralnego odrodzenia ludzkości, zarówno w życiu prywatnym, jak i publicznym. Przewodnictwo Polski, pomimo wad narodowych, które dostrzegał, ma się realizować przez wytrwałą pracę opartą na wartościach i zasadach moralnych chrześcijaństwa ${ }^{58}$.

Powołaniem Polski jest więc orędownictwo moralności w życiu międzynarodowym i społecznym, wprowadzenie jej zasad w czyn, wdrażanie praw chrześcijańskich w dzieje ${ }^{59}$. Oto istota mesjanizmu polskiego w wydaniu Wojciecha Dzieduszyckiego. W swoim dziele poświęconym wprost mesjanizmowi pokazywał, jak tego dokonać: „Nasza cywilizacja, potężniejąc, naród krzepić, wznosić będzie, stanie się arką, w której zawarte będą wszystkie prawdy moralne i społeczne, mające świat obronić od ruiny, cywilizację chrześcijańską do

56 Por. T. Zawojska, Religijno-patriotyczne podstawy, dz. cyt., 34.

57 W. Dzieduszycki, Mesjanizm polski a prawda dziejów, dz. cyt., 638-639.

58 Por. T. Zawojska, Religijno-patriotyczne podstawy, dz. cyt., 35, 39-40.

59 Por. A. Kosiecka-Pajewska, Zachowawcza myśl polityczna, dz. cyt., 226. Por. T. Jakubiec, Wojciech Dzieduszycki, dz. cyt., 46-47. 
wyższych doprowadzić celów; obojętność i niechęć przezwycięży, cudzoziemców zmusi, żeby ją najpierw uznali, potem podziwiali, nieprzyjaciołom miecz prześladowczy z rąk wytrąci; a gdy wytrwamy w cnocie, a pracować będziemy ustawicznie, ujrzymy, iż drudzy kłamstwem się zatruli, my wyrośliśmy, my przewodzimy, myśmy u czoła! Tak, to być może, to być musi, jeśli zechcemy przyjąć na siebie wielkie powołanie, które konieczność dziejowa na nas nakłada. Wielkość dziejowa, zbawienie narodów zależy od ich własnej wytrwałej, cnotliwej, a roztropnej pracy. Kochacie Polskę, więc pracujcie, nie leńcie się, a wielka w dziejach nagroda, narodu naszego nie minie!"60. Każdy więc człowiek jest moralnie odpowiedzialny nie tylko za siebie, ale również za kierunek rozwoju cywilizacji. Ten obowiązek należy realizować w oparciu o prawa Boże, gdyż tylko w ten sposób uniknie się katastrofy. Taką samą misję mogą realizować również narody, a szczególnie do tego predestynowany jest naród polski ${ }^{61}$.

\section{RYZYKO BEZWYZNANIOWEGO ŚWIATA}

Przypomnienie myśli filozoficznej Dzieduszyckiego wydaje się sensowne, a ona sama nadal aktualna. Poznając jego teksty, czytelnik przekonuje się, że tak jest. Głos dziewiętnastowiecznego myśliciela wpisuje się we współczesne dyskusje światopoglądowe, w debatę nad istotą tożsamości europejskiej i nad kształtem jej cywilizacji. Przestrogi z przeszłości mogą nam pomóc lepiej ukształtować naszą przyszłośćc ${ }^{2}$. Gdy dziś, na początku XXI wieku, czytamy teksty polskiego filozofa sprzed ponad stu lat, to - choć mamy świadomość dystansu czasowego i czujemy, że wiele jego tez i przemyśleń może być obecnie uważanych za kontrowersyjne, a może nawet banalne jedno wydaje się zaskakująco aktualne: współczesna strukturalna

60 W. Dzieduszycki, Mesjanizm polski a prawda dziejów, dz. cyt., 652-653.

61 Por. T. Zawojska, Religijno-patriotyczne podstawy, dz. cyt., 35-36.

62 Por. T. Zawojska, Ku chrześcijańskiej wspólnocie Europy, dz. cyt., 272. 
niechęć do religii i jej zadań w życiu społecznym. Obecnie wciąż na nowo przywołuje się i przywraca ideę „bezwyznaniowości”, o której tak wiele pisał Dzieduszycki. Liczne środowiska i instytucje nadal widzą w religii przeszkodę dla postępu w niemalże każdej dziedzinie: moralnej, społeczno-politycznej, naukowej czy kulturalnej. Jesteśmy świadkami przywoływania haseł zarówno o konieczności radykalnego rozdziału państwa od Kościoła, polityki od wiary (religia sprawą prywatną, bez jakiegokolwiek odniesienia do życia publicznego), jak i negowania religii jako takiej. Idea państwa całkowicie laickiego i wymóg absolutnej neutralności światopoglądowej inspiruje dziś wiele osób do zmagania się o nowy wymiar życia społecznego, a czasem wręcz przejawia się w czynnej niechęci wobec wszelkich przejawów religijności ${ }^{63}$.

Niewątpliwie jest to skutek, obecnych szczególnie w Europie, silnych tendencji sekularyzacyjnych. Od kilku dziesięcioleci jesteśmy świadkami podważania wartości religii jako niezbędnego składnika życia społecznego, a tym bardziej politycznego. Czy w takiej perspektywie ma zatem sens przywoływanie refleksji myśliciela $z$ innej historycznej i obyczajowej epoki? Sądzę, że tak, przynajmniej z dwóch powodów: po pierwsze dlatego, że jak już wspomniałem, aktualna jest sama kategoria „bezwyznaniowości”, a co za tym idzie i próba negowania religii jako zjawiska wartościowego. Po drugie, warto korzystając z przemyśleń i obserwacji Dzieduszyckiego - spróbować odpowiedzieć na pytanie: jaki świat wyłoni się, gdy uwolnimy społeczność i politykę od religijnych inspiracji?

Dzieduszycki mocno zaznaczał, że samo osiągnięcie bezwyznaniowości jako stanu społecznego nie daje jeszcze odpowiedzi na pytanie - jaka inna niż religijna (w przypadku Europy - chrześcijańska) rzeczywistość ma wspierać ludzi i ich wspólnoty, konstruować paradygmaty, określać wartości i wybory? Oczywiście wiemy, że

63 Por. J. Grzybowski, Szukając światła w nocy świata. Rozważania o kulturze, polityce i religii, Kielce 2018, 134-136. 
dziś pewne odpowiedzi się pojawiają. Dla wielu socjologiczną rolę religii, jako uniwersalnego spoiwa społecznego, pełni w jakimś sensie odpowiednio sprofilowana kultura, rynek informacji medialnych i kapitalistyczna ekonomia. Przestrzenie te są dziś najlepszym towarem i najbardziej pożądanym dobrem. Czeski myśliciel T. Halik twierdzi, że media przejęły najwięcej z tradycyjnych ról religii - interpretują świat, decydują o kwestii prawdziwości i ważności problemów, proponują wielkie symbole, styl życia, kreują wydarzenia i swoiste społeczne „sakramenty” - znaki tego co ulotne, tajemnicze, dalekie i niewidzialne ${ }^{64}$. Jest to swoisty substytut religii rozumianej w szerokim etymologicznym, socjologiczno-etnologicznym, znaczeniu tego pojęcia - religare - „łączyć”, „wiązać”, „budować wspólnotę więzi”65. Tak definiowana „religia” może przenikać wszystkie najważniejsze dziedziny życia, w tym także politykę, rozumianą jako troska o dobro wspólne, budowanie przyszłości i wysiłek w dążeniu do zadanych sobie celów. Coraz więcej słychać głosów, że społeczność, naród, państwo czy inne wspólnoty, z konieczności definiowane dziś demokratycznie, potrzebują pewnego kwantum wspólnych wartości, które połączą pokolenia. Bez tego żadne społeczeństwo nie może ani trwać, ani się rozwijaćc6. Wynika to $z$ oczywistego faktu, że każda ze wspólnot, tym bardziej polityczna, musi realizować jakoś

64 Por. T. Halik, Europa pomiędzy laickością a chrześcijaństwem, Więź (2011)2-3, 127.

65 Zob. E. Durkheim, Elementarne formy życia religijnego. System totemiczny w Australii, tłum. z ang. A. Zadrożyńska, Warszawa 1990. To sam Durkheim, syn rabina, który porzucił konfesję i przyjął światopogląd ateistyczny, rozwijał ideę globalnej religii obywatelskiej, pisząc o „kulcie człowieka”, „religii ludzkości” czy „religii prawa”. Kluczową rolę w tej świeckiej religii miała odgrywać państwowa edukacja, nakierowana na wychowanie zdolnych do poświęcenia obywateli. Zob. R.A. Wallace, Ėmile Durkheim and the Civil Religion Concept, Review of Religious Research 18(1977), 287-290; A. Comte-Sponville, Duchowość ateistyczna. Wprowadzenie do duchowości bez Boga, tłum. z fr. E. Aduszkiewicz, Warszawa 2011, 32; M. Gauchet, Religia i demokracja, tłum. z fr. M. Warchala, Przegląd Polityczny (2013)118, 83.

66 Por. J. Grzybowski, Religia jako więź - zwodnicza nadzieja polityki, Studia Philosophiae Christianae 47(2011)2, 218. 
zdefiniowane dobro (wartości). Tym samym oznacza to, że w społeczeństwie (jakkolwiek paradoksalnie to brzmi) nie da się zrealizować polityki bez „religii”, czyli bez odniesień społecznych zakotwiczonych w argumentach na rzecz więzi. A zatem polityka, chcąc nie chcąc, staje się swoistym urzeczywistnieniem wartości, aksjologicznych zachowań i reguł. Konsekwencją tego jest przekonanie, że dla wielu ludzi to relacje społeczne i polityczne, a nie religia stają się niejako „duszą" współczesnego, wielokulturowego i wielowątkowego świata ${ }^{67}$.

Jeśli zatem bezwyznaniowo usposobiony człowiek ma w życiu jednostkowym i społecznym osiągnąć pojednanie z samym sobą, to zawsze będzie szukał racjonalnych i moralnych sensów swej egzystencji. Oznacza to, że w projekcie ateistycznego społeczeństwa „wielkiej separacji” - jak nazwał to zjawisko Mark Lilla - społeczeństwa oddzielonego od konfesyjnych racji, argumentów i wpływów, nie da się żyć bez więzi. Stąd współcześni ateiści, pragnący oddzielenia religii od polityki, mówią jednocześnie: można nie wierzyć w Boga, a jednocześnie żyć w sposób prawy, moralny i przyzwoity ${ }^{68}$. W swoich pracach i rozważaniach pokazują, że choć w laickiej społeczności należy być świadomym nieobecności Boga, którego „śmierć” stwierdzono i ogłoszono w XX wieku, to przede wszystkim należy z nadzieją starać się stworzyć lepszy świat. Każda kultura, w tym także kultura Zachodu potrzebuje jakiegoś etycznego fundamentu ciągłości i tradycji, jednak - w oczach ponowoczesnych myślicieli - rozumianej nie jako wyznanie (konfesja, wiara), ale jako pewien kod kulturowy, swoiste spoiwo zarówno życia społecznego jak i politycznego ${ }^{69}$. Sa to, $z$ jednej strony zeświecczone zasoby kultury religijnej włączone w system polityczny, z drugiej mentalne akty wspólnoty, tradycje,

67 Por. T. Eagleton, Rozum, wiara i rewolucja. Refleksje nad debatą o Bogu, tłum. z ang. W. Usakiewicz, Kraków 2010, 147; G. Ritzer, Magiczny świat konsumpcji, tłum. z ang. L. Stawowy, Warszawa 2009, 27nn.

68 Por. M. Lilla, Bezsilny Bóg. Religia, polityka i nowoczesny Zachód, tłum. z ang. J. Mikos, Warszawa 2009, 230.

69 Por. M. Szulakiewicz, Religia i czas, Toruń 2008, 134-136. 
rodzaje habitualnych zachowań i związanego z nim etosu. Stają się one (szczególnie dla osób określających się jako niewierzący, agnostycy, ateiści) płaszczyzną stworzenia motywacji dla ludzkich postaw w spluralizowanym, migracyjnym, heterogenicznym, zmiennym i hybrydowym świecie ${ }^{70}$. Etos ludzki żyje przecież - przekonują zwolennicy laickiego społeczeństwa - w różnorodnych praktykach życia społecznego, w ludzkiej kulturze wziętej w całym jej bogactwie (filozofia, sztuka, nauka, artyzm). Duch bowiem trwa w twórczej aktywności człowieka. Bez symbolicznych struktur, dzięki którym zostaje w społeczeństwo wpuszczona nadzieja wykraczająca poza doraźne interesy i doczesne kalkulacje, społeczeństwa i jednostki tracą orientację ${ }^{71}$.

We współczesnych propozycjach bezwyznaniowych społeczności wybrzmiewa zatem kluczowe dla wielu ateistycznych środowisk pragnienie zbudowania świata, którego reguł nie określają prawa i zasady religijne. W takim świecie nie ma konieczności jakiegokolwiek mesjanizmu, tak ważnego dla romantyków XIX wieku i propagowanego w twórczości Dzieduszyckiego. Wszystkie nadzieje są ulokowane docześnie w „tu i teraz”. Jednocześnie jest tu widoczne szczere pragnienie $\mathrm{i}$ wiara $\mathrm{w}$ realizację państwa sprawiedliwości i pokoju, życzliwości i dobra, którego prerogatywy będą płynąć jedynie $z$ doczesnych uwarunkowań ${ }^{72}$.

Czy takie tezy nie falsyfikują ostrzeżeń i wywodów Wojciecha Dzieduszyckiego? Odpowiadając, zauważmy najpierw, że nadzieja

70 Implikuje to oczywiście praktykę, w której rytuały, instytucje, formy stają się najważniejsze. Bez głębokiego doświadczenia przemiany, religia staje się formą samą w sobie i celem dla samej siebie. Powodem tego zjawiska jest rozejście się doświadczenia religijnego (osobistego zaangażowania) z religijnymi rytuałami. Zob. K. Dobbelaere, Sekularyzacja. Trzy poziomy analizy, tłum. z fr. R. Babińska, Kraków 2008, 67nn.

71 Por. T. Eagleton, Rozum, wiara i rewolucja, dz. cyt., 167; A. Delbanco, The Real American Dream: A Meditation on Hope, Harvard University Press 2000, 56; S. Kruszyńska, Zrozumieć niewiarę. Filozoficzne wyznania niewiary w nowożytnej myśli francuskiej, Gdańsk 2011, 380.

72 Por. P. Valadier, Nędza polityki i moc religii, tłum. z fr. T. Żeleźnik, Warszawa 2010, 20-22. 
na zbudowanie lepszego świata jest stara jak sama ludzkość, ale przekonanie, że można tego dokonać bez Boga, a nawet wbrew ideom religijnym pojawiła się - zaznaczał to mocno polski myśliciel - stosunkowo niedawno: w połowie XVIII wieku. Ateizm jest zatem projektem modernizacyjnym - chce zmienić świat na lepsze, pragnąc społeczności bez konfesyjnej narracji i jej uzasadnień. Czy wobec takich, dziś mocno promowanych tez, nie warto rozważyć wskazywanych przez Dzieduszyckiego konsekwencji wyparcia religii z życia publicznego?

Czy skutkiem ogłoszonej „śmierci Boga” i schyłku religii nie jest ryzyko utraty woli dążenia ku dobremu? Czy za utratą wiary nie następuje utrata motywacji, autorytetu, zaufania? $\mathrm{W}$ parze $\mathrm{z}$ tym idzie kryzys prawdy w stosunkach międzyludzkich, niebezpieczeństwo braku odpowiedzialności za słowo, czysto utylitarny stosunek do człowieka, zatrata poczucia prawdziwego dobra wspólnego i łatwości, z jaką ulega ono alienacji, wreszcie desakralizacja, która może przerodzić się w dehumanizację. Człowiek i społeczeństwo, dla którego już nic nie jest „święte”, mogą ulec moralnej dekadencji ${ }^{73}$. Czy potworne doświadczenia XX wieku, który stał się areną niewyobrażalnych zbrodni dokonanych przez ludzi zaciekle walczących z religią (Stalin, Hitler, Mao, Pol Pot), nie potwierdziły intuicji polskiego filozofa, który w haśle bezwyznaniowości widział nabrzmiewające niebezpieczeństwa?

Uważam zatem, że argumenty Wojciecha Dzieduszyckiego stanowią swoistą przestrogę dla tych wszystkich, którzy podnoszą dziś hasła „bezwyznaniowości”. Polski myśliciel starał się pokazać, że wyrugowanie religii z życia publicznego wcale nie przynosi postępu - wręcz przeciwnie - może prowadzić do barbaryzacji społeczeństw i jednostek. $Z$ perspektywy polskiego historiozofa religia jest wręcz konieczna - daje społeczeństwom, narodom i państwom szansę utrzymania jedności wspólnotowej oraz narodowej tożsamości. Jest

73 Por. H. Pfeil, Tragizm negacji Boga, tłum. z niem. A. Chojecki, Katowice 1947, 8. 
pożyteczna, jeśli chodzi o nadawanie czy też wzmacnianie poczucia sensu istnienia, chroni przed popadaniem w pesymizm i postawy dekadenckie, przyczyniając się w ten sposób do utrzymania zdrowej kondycji społeczeństwa. Przede wszystkim zaś staje się źródłem wartości i zasad moralnych, na których z powodzeniem można budować dobrą i pomyślną przyszłość każdego państwa. Przestrzenią rozwoju takich moralnych postaw jest dla Dzieduszyckiego w sposób szczególny chrześcijaństwo, którego zasady warto afirmować i wprowadzać do życia publicznego narodów. Czytając jego teksty sprzed ponad wieku warto dostrzec ich proroczą wymowę. Dzieduszycki ostrzega, że odejście od religii w imię postępowo ujętej bezwyznaniowości niesie w sobie poważne ryzyko utraty społecznego etosu, który zawsze przynosi ze sobą religia.

\section{BIBLIOGRAFIA}

Comte-Sponville A., Duchowość ateistyczna. Wprowadzenie do duchowości bez Boga, tłum. z fr. E. Aduszkiewicz, Wydawnictwo „Czarna Owca”, Warszawa 2011.

Daszyk K.K., Osobliwy Podolak, W kregu myśli historiozoficznej i spoteczno-politycznej Wojciecha hr. Dzieduszyckiego, Zeszyty Naukowe Uniwersytetu Jagiellońskiego, Kraków 1993.

Delbanco A., The Real American Dream: A Meditation on Hope, Harvard University Press 2000.

Dobbelaere K., Sekularyzacja. Trzy poziomy analizy, tłum. z fr. R. Babińska, Zakład Wydawniczy Nomos, Kraków 2008.

Durkheim E., Elementarne formy życia religijnego. System totemiczny w Australii, tłum. z ang. A. Zadrożyńska, PWN, Warszawa 1990.

Dzieduszycki W., Dokąd nam iść wypada?, w: Tenże, Dokąd nam iśc wypada?; Mesjanizm polski a prawda dziejów, Ośrodek Myśli Politycznej, Kraków 2012.

Dzieduszycki W., Listy czytelnika, Księgarnia Gubrynowicza i Schmidta, Lwów 1893.

Dzieduszycki W., Listy o wychowaniu, Nakładem autora drukarnia Piller i Spółka, Lwów 1892.

Dzieduszycki W., Listy ze wsi, seria I-II, Nakładem „Gazety Narodowej” drukarnia Piller i Spółka, Lwów 1889-1890. 
Dzieduszycki W., Mesjanizm polski a prawda dziejów, w: Tenże, Dokąd nam iść wypada?; Mesjanizm polski a prawda dziejów, Ośrodek Myśli Politycznej, Kraków 2012.

Dzieduszycki W., Wiek XIX, Główny Skład w Księgarni Spółki Wydawniczej Polskiej, Kraków 1900.

Dzieduszycki W., Uczone fantazje, Drukarnia „Czasu”, Kraków 1871.

Eagleton T., Rozum, wiara i rewolucja. Refleksje nad debatq o Bogu, thum. $\mathrm{z}$ ang. W. Usakiewicz, Wydawnictwo Uniwersytetu Jagiellońskiego, Kraków 2010.

Gauchet M., Religia i demokracja, tłum. z fr. M. Warchala, Przegląd Polityczny (2013)118, 82-85.

Grzybowski J., Religia jako więz-zwodnicza nadzieja polityki, Studia Philosophiae Christianae 47(2011)2, 209-229.

Grzybowski J., Szukając światta w nocy świata. Rozważania o kulturze, polityce i religii, Wydawnictwo Jedność, Kielce 2018.

Halik T., Europa pomiędzy laickościq a chrześcijaństwem, Więź (2011)2-3, 127-133. Jakubiec T., Wojciech Dzieduszycki. Pisarz, estetyk, fllozof, Księgarnia Akademicka, Kraków 2009.

Kelly J.N.D., Encyklopedia papieży, tłum. z ang. T. Szafrański, Państwowy Instytut Wydawniczy, Warszawa 1997, 435-438.

Kosiecka-Pajewska A., Zachowawcza myśl polityczna w Galicji w latach 1864-1914, Wydawnictwo Naukowe im. A. Mickiewicza w Poznaniu, Poznań 2002.

Krasiński Z., Przedświt, Krakowska Spółka Wydawnicza, Kraków 1924.

Kruszyńska S., Zrozumieć niewiarę. Filozoficzne wyznania niewiary w nowożytnej myśli francuskiej, Słowo/obraz terytoria, Gdańsk 2011.

Lilla M., Bezsilny Bóg. Religia, polityka i nowoczesny Zachód, tłum. z ang. J. Mikos, Wydawnictwo W.A.B., Warszawa 2009.

Majka J., Katolicka Nauka Spoteczna. Studium Historyczno-doktrynalne, Wydawnictwo: Fundacja Jana Pawła II. Polski Instytut Kultury Chrześcijańskiej, Rzym 1986.

Pfeil H., Tragizm negacji Boga, tłum. z niem. A. Chojecki, Nakładem Księgarni św. Jacka, Katowice 1947.

Ritzer G., Magiczny świat konsumpcji, tłum. z ang. L. Stawowy, Warszawskie Wydawnictwo Literackie „Muza”, Warszawa 2009.

Szulakiewicz M., Religia i czas, Wydawnictwo Naukowe Uniwersytetu Mikołaja Kopernika, Toruń 2008.

Valadier P., Nędza polityki i moc religii, tłum. z fr. T. Żeleźnik, Instytut Wydawniczy Pax, Warszawa 2010. 
Wallace R.A., Emile Durkheim and the Civil Religion Concept, Review of Religious Research 18(1977), 287-290.

Zawojska T. Dzieduszycki Wojciech, w: Powszechna Encyklopedia Filozofii, t. II, red. A. Maryniarczyk, Polskie Towarzystwo Tomasza z Akwinu, Lublin 2001, 788-794.

Zawojska T., Ku chrześcijańskiej wspólnocie Europy. Refleksje myślicieli polskich z początku XX stulecia. W. Dzieduszycki i M. Zdziechowski, w: Światopoglądowe odniesienia flozofii polskiej, Wydawnictwo KUL, Lublin 2011, 269-289.

Zawojska T., Od epistemologii do historiozofii. Poglady filozoficzne Wojciecha Dzieduszyckiego, Wydawnictwo KUL, Lublin 2011.

Zawojska T., Religijno-patriotyczne podstawy narodowych aspiracji Polaków u progu XX stulecia w świetle pogladów Wojciecha Dzieduszyckiego, Cywilizacja. O nauce, moralności, sztuce i religii (2014)48, Fundacja Servire Instytut Edukacji Narodowej, Kraków 2014, 29-42.

\title{
A CRITICAL ANALYSIS OF WOJCIECH DZIEDUSZYCKI'S IDEA OF "IRRELIGIOUSNESS"
}

\begin{abstract}
This article considers the polemic of the Polish philosopher Wojciech Dzieduszycki (1848-1909) against one of the progressive slogans of the 19th century. Dzieduszycki himself described this slogan as „irreligiousness”. This paper analyses Dzieduszycki's arguments regarding the negative consequences following the exclusion of religion from the public sphere, in both past and Dzieduszycki's times, and also shows the extremely positive role of religion in the lives of individuals, states, nations, and even entire civilizations. Without religion, the Polish thinker claimed, communities degrade and die. An interesting and nowadays very important discussion about the role of religion in social life has been paired in the article with the idea of „Polish messianism” disseminated by Dzieduszycki. (as an appropriate response to the civilisational crisis), as well as with the radical secularism in our current culture and politics.
\end{abstract}

Keywords: religion, irreligiousness, state, society, nation, Polish messianism, the idea of progress, civilization.

\footnotetext{
ARKADIUSZ LAO

arkadiuszlao@gmail.com

Uniwersytet Kardynała Stefana Wyszyńskiego w Warszawie

Wóycickiego 1/3, 01-938 Warszawa

ORCID: 0000-0003-2021-6952
}

Doi: $10.21697 /$ spch.2020.56.1.02 